\title{
NEW TESTAMENT BOOK EPIGRAMS \\ Some New Evidence from the Eleventh Century
}

KLAAS BENTEIN, FLORIS BERNARD, KRISTOFFEL DEMOEN, MARC DE GROOTE / GENT

In his study on the Byzantine epigram, Marc Lauxtermann singles out the "book epigram" as a category apart. ${ }^{1}$ These poems, encountered frequently in Byzantine manuscripts, range from unpretentious scribbles of the scribe commenting on the text, to elaborate poetic ornaments which aspire to add to the value of the book. They form a kind of 'paratext' beside the main text of manuscripts.

Only seldom do distinctive features of this particular genre receive a scholarly treatment on their own. In earlier studies, they are merely collected, or investigated to determine the date or provenance of the manuscripts. ${ }^{2}$ More recently, however, a number of studies has focused on the verses themselves: their content, ${ }^{3}$ function, ${ }^{4}$ structure, ${ }^{5}$ lay-out, ${ }^{6}$ categorization, ${ }^{7}$ etc.

It is our intention to edit, translate and comment on some epigrams that we have come across during our extended research of eleventh-century manuscripts. ${ }^{8}$ All of them come from manuscripts containing the New Testament or

We wish to express our sincere gratefulness to the anonymous reviewer who has made some astute remarks and proposals, several of which we were glad to accept when revising this article for publication.

1 Cf. M.D. Lauxtermann, Byzantine Poetry from Pisides to Geometres. Wien 2003, 197 : "book epigrams are poems that are intimately related to the production of literary texts and manuscripts". At p. 202-203 the importance of studying book epigrams is stressed.

2 E.g. E. Follieri, Epigrammi sugli evangelisti dai codici Barberiniani greci 352 e 520,

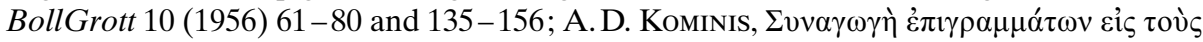

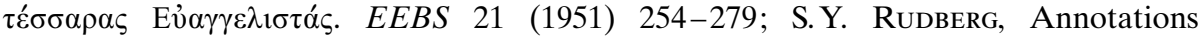
historiques et adscripta métriques contenus dans les manuscrits de Basile de Césarée, Scriptorium 15 (1961) 61-67; H. von Soden, Die Schriften des Neuen Testaments in ihrer ältesten erreichbaren Textgestalt hergestellt auf Grund ihrer Textgeschichte. Teil 1, Vol. I. Göttingen 1902, 377-387.

3 E.g. H. Hunger, Schreiben und Lesen in Byzanz: Die byzantinische Buchkultur. München 1989, 94-99.

4 E.g. I. ŠEvčEnKo, Captions to a David Cycle in the Tenth-Century Oxford Auct. D. 4. 1, in: C. Scholz /G. Makris (eds.), Polypleuros Nous. Miscellanea für Peter Schreiner zu seinem 60. Geburtstag. München 2000, 324-341.

5 E.g. E. Gamillscheg, Struktur und Aussagen der Subskriptionen griechischer Handschriften, in: E. Condello/G. De Gregorio (eds.), Scribi e colofoni. Le sottoscrizioni di copisti dalle origini all'avvento della stampa. Spoleto 1995, 417-421.

6 E.g. W. Hörandner, Visuelle Poesie in Byzanz, JÖB 40 (1990) 1-42.

7 E.g. LauXTERMANN (cf. note 1) 197-198.

8 We would like to thank the Research Foundation - Flanders (FWO) for enabling this research, which resulted in the collecting of 568 epigrams from 414 eleventh century manuscripts. It was supervised by K. Demoen and M. De Groote, and carried out by K. 
commentaries on it. Some of them are unedited, while the second one is a conflation of known epigrams and the third an unknown version of a previously edited poem. As this genre has a particular tendency to be reused and adapted, the texts presented here can be considered as a chronological cross-section in an extensive chain of recyclable material.

\section{The four evangelists}

Source: Paris. Coisl. 199, f. 9. This manuscript (328 folios) was written on parchment and measures 18.9 by $14 \mathrm{~cm}$. The main text consists of the four Gospels (ff. 1-8v, 25-157v), the Acts of the Apostles (ff. 159-200), the Catholic Letters (ff. 200v-204v), Paul's Letters (ff. 221-236) and the Apocalypse (ff. 311-325v). Devreesse dated the manuscript to the eleventh century. ${ }^{9}$

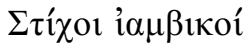

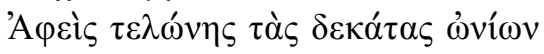

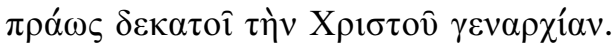

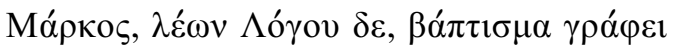

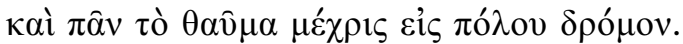

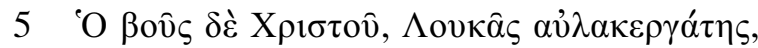

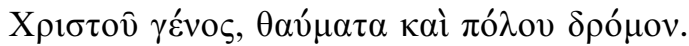

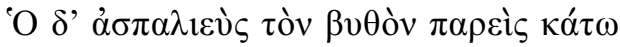

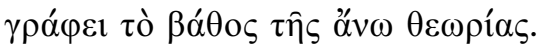

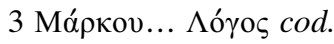

Iambic verses

The publican has ceased taking tithe of goods

and now gently takes tithe of the genealogy of Christ.

Mark, the lion of the Word, writes about the baptism

and the whole miracle until the Ascension.

The ox of Christ, Luke, the ploughman, writes about the birth of Christ, his miracles and Ascension.

The angler, having left the deep water below, now writes about the depth of the higher contemplation.

Bentein, in close cooperation with F. Bernard. Since the completion of this article, our research group at Ghent University has been awarded a substantial grant by the 'Hercules programme' of the Flemish government, which will enable us to enlarge the collection and to construct a searchable database of Byzantine book epigrams. A first version of this database should be accessible online in the foreseeable future.

9 R. Devreesse, Catalogue des manuscrits grecs. Le fonds Coislin. Paris 1945, 176. 
This poem, preceding the Gospels, has been written in honour of the four evangelists. Its structure is quite transparent: in each of the four distichs, the evangelist is mentioned directly or obliquely, and the typical features of his particular gospel are presented. Within this overall symmetry, the four distichs clearly fall into two types: Matthew and John are only indicated by a reference to their former profession (with a typical antithetical pun), whereas Mark and Luke are named and accompanied by their animal symbol. ${ }^{10}$ This could either be a matter of conscious variation or an indication of the combination of distichs from various sources.

The poem uses some fairly exceptional and high-brow words, such as $\dot{\alpha} \sigma \pi \alpha-$ $\lambda ı \varepsilon v \varsigma$ (v. 7; a most unusual denomination for John) and $\alpha \hat{\jmath} \lambda \alpha \kappa \varepsilon \rho \gamma \alpha \dot{\tau} \eta \varsigma$ (v. 5). On the other hand, the designation of Matthew as a $\tau \varepsilon \lambda \omega v \eta \varsigma$ in the first verse of

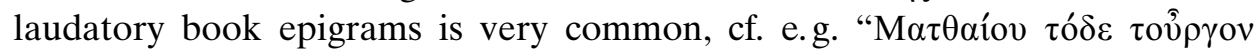

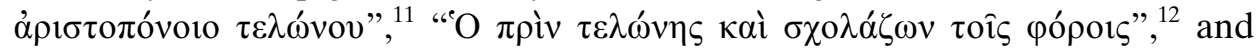

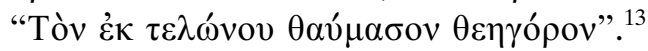

The poet also differentiates between the content of the four Gospels. The three synoptic ones are characterised by the events that mark their openings and endings. Book epigrams on the evangelists mention these features

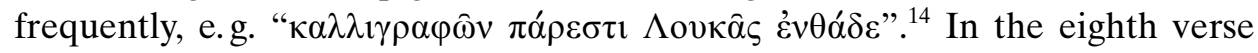

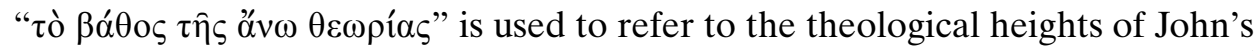

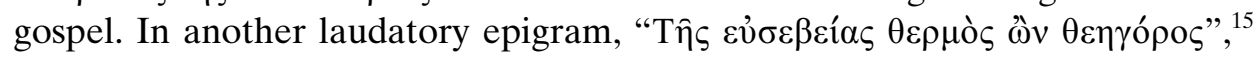

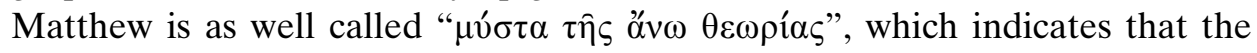
formula was not exclusively associated with John.

The prosodic technique of this poem concurs with the principle of visibility: the quantity of the vowels is respected, except for dichrona (cf. e.g. v. $8 \beta \alpha \dot{\theta} \theta$ o

10 The association of the evangelists with the four living creatures mentioned in Ez. 1:10 and Ap. 4:7 is attested as early as the second century, with Irenaeus' Against Heresies (3.11.8). Although there was some inconsistency in the beginning, by the end of the fourth century a fixed representational order was established: Matthew was symbolized by the angel or human, Mark by the lion, Luke by the ox and John by the eagle. Cf. O. BöCHER, Evangelistensymbole, in: ${ }^{4}$ Religion in Geschichte und Gegenwart II (1999) 1734-1735.

11 Athous Lavr. A 21, f. 78; Gotting. Theol. 28, f. 6v; Mosq. Len. Bib. 12, f. 1v; Petropolit. Gr. 249 Granstrem, f. 13v; Vatic. Gr. 757, f. 2; Vindobon. Suppl. Gr. 50*, f. 24. Edited by FolLIERI (cf. note 2) 79. The book epigrams mentioned in this article are referred to by their initial verse, according to the usage of I. VAssis, Initia Carminum Byzantinorum. Berlin/New York 2005, an invaluable reference work that was obviously very useful for the compilation of the database.

12 Athous Vat. 937, f. 13v.; Budapest. Gr. Bibl. Sc. Univ. 1, f. 10; Prag. Bibl. Nat. Univ. XXV B 7, f. 11v; Marc. Gr. Class. I, 18, f. 2v. Edited by Kominis (cf. note 2) 264.

13 Athous Lavr. A 22, f. 77v; Vindobon. Suppl. Gr. 50*, f. 7. Edited by Kominis (cf. note 2) 264-265.

14 Parm. Bibl. Pal. f. De-Ross. 1 (location unknown). Edited by Kominis (cf. note 2) 272.

15 Athen. Gr. 2, f. 8v. Edited by Kominis (cf. note 2) 263-264. 


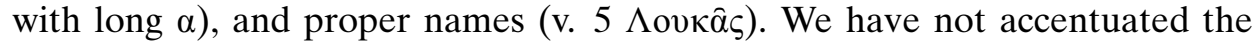
particle $\delta \varepsilon$ in v. 3 , following the manuscript. According to the accentual rules of the dodecasyllable, the seventh syllable just before the verse pause cannot have an accent. For that reason, many scribes regarded words as $\delta \dot{\varepsilon}$ in that position as an enclitic, and consequently did not accentuate it. ${ }^{16}$

\section{Luke and the Acts of the Apostles}

Source: Vindobon. Theol. Gr. 302, f. 16r. This manuscript (367 folios) was written on parchment and measures 18 by $13 \mathrm{~cm}$. The main text consists of the Acts of the Apostles (ff. 18r - 101r), the Catholic Letters (f. 101v-140v), Paul's Letters (ff. 141r - 312) and John's Apocalypse (ff. 314r - 353v). Hunger dated the manuscript to the middle of the eleventh century. ${ }^{17}$

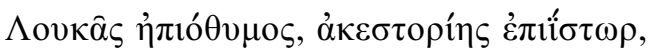

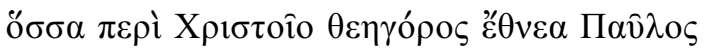

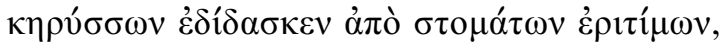

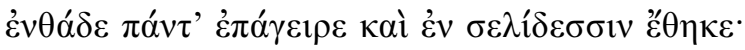

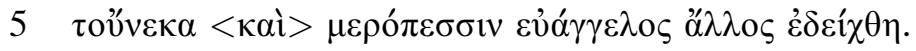

5 kaì addidimus, nixi Il. IX.159, XIII.728 et Greg. Naz. passim, coll. ceteris versionibus huius carminis

Gentle-hearted Luke, versed in the knowledge of medicine, has collected here and put on paper all the things

about Christ that Paul, divinely inspired, preached and taught to the gentiles, with his highly-praised mouth.

Therefore he appeared to the mortals as another evangelist.

This epigram is not entirely new: the first verse is also the initial verse of numerous epigrams in honour of Luke the Evangelist. ${ }^{18}$ The remainder of our

16 I. Hilberg, Ein Accentgesetz der byzantinischen Jambographen, BZ 7 (1898) 337-365, esp. 355-356. Cf. also P. MAAs, Der byzantinische Zwölfsilber, BZ 12 (1903) 278-323, esp. 313. Some editors take over the practice of the scribe not to put an accent on these words, cf. G. Papagiannis (ed.), Theodoros Prodromos. Jambische und hexametrische Tetrasticha auf die Haupterzählungen des Alten und des Neuen Testaments. Wiesbaden 1997.

17 H. Hunger, Katalog der griechischen Handschriften der Österreichischen Nationalbibliothek: Codices Theologici 201-337. Wien 1992, 345.

18 Athous Lavr. A 21, f. 201v; Gotting. Theol. 28, f. 83v; Mosq. Len. Bib. 10, f. 132v; Mosq. Len. Bib. 12, f. 122v; Petropolit. Gr. 249 Granstrem, f. 133; Vindobon. Suppl. Gr. 50*, f. 158. Edited by Kominis (cf. note 2) 270. 
poem forms an epigram of four verses that is equally widespread in contemporary New Testament manuscripts, and normally accompanies the gospel of Mark. ${ }^{19}$ Our scribe made only two noticeable deviations from the

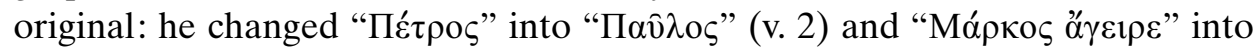
" $\pi \alpha \alpha^{\prime} \tau$ ' غ̇ $\alpha_{\gamma} \gamma \varepsilon \varphi \rho \varepsilon "$ (v. 4). By doing so, the praise is awarded to Paul and Luke, instead of Peter and Mark. This way, the scribe succeeds in fitting this existing poem into its new context. Since our poem precedes a text of the Acts of the Apostles, this combination and adaptation of two traditional poems - which indeed often occur in the same manuscript - lead to the composition of a new one, but now in honour of Luke and his acts, and of Paul, the protagonist in these acts.

This poem is written in dactylic hexameters, which is rather unusual. ${ }^{20}$ These verses, albeit prosodically correct, show some peculiarities in their versifying technique: all but three of the feet are dactyls. This evolution towards a hexameter without or with only one spondee is typical of later Byzantine hexameters, and marks the end of an evolution discernible from Late Antiquity onwards. ${ }^{21}$ This conformity also extends to the caesura: the caesura

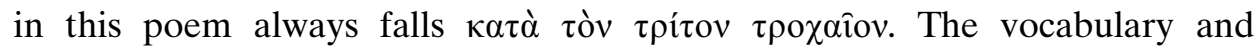
morphology are distinctly epic; some words, however, do not occur in Homer but only in later hexametric poetry (e.g. $\sigma \varepsilon \lambda i \varsigma$, which appears well after Homer).

\section{Commentary on the Praxapostolus}

Source: Paris. Coisl. 26, f. 1v. This manuscript (381 folios) was written on parchment and measures 29.8 by $23.3 \mathrm{~cm}$. The main text consists of Ps.Oecumenius' Commentary on the Praxapostolus (ff. 2-379). It apparently

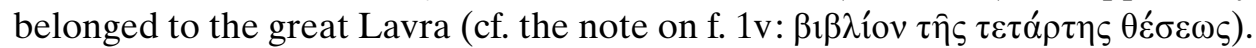
Halkin dated the manuscript to the tenth or eleventh century. ${ }^{22}$

19 Athous Lavr. A 34, f. 76; Gotting. Theol. 28, f. 53; Monac. Gr. 518 (location unknown); Mosq. Len. Bib. 10, f. 83v; Mosq. Len. Bib. 12, f. 78v; Petropolit. Gr. 208 Granstrem, f. 355; Petropolit. Gr. Libr. 249 Granstrem, f. 87v; Vatic. Gr. 349, f. 113(?); Vindobon. Suppl. Gr. 50*, f. 106. Edited by Kominis (cf. note 2) 267. These manuscripts agree in reading $\kappa \alpha i ̀$ in the last verse.

20 The dodecasyllable is by far the dominant meter for book epigrams. Out of the 568 epigrams that our database contains, 518 are written in dodecasyllables.

21 Cf. E.M. van Opstall, Jean Géomètre. Poèmes en hexamètres et en distiques élégiaques. Édition, traduction, commentaire. Leiden 2008, 83; for the ancient evolution, see G. Agosti/F. Gonnelli, Materiali per la storia dell'esametro nei poeti cristiani greci, in: M. Fantuzzi / R. Pretagostini (eds.), Struttura e storia dell'esametro greco. Roma 1995, 289-434.

22 F. Halkin, Manuscrits grecs de Paris. Inventaire hagiographique. Paris 1968, 238. 


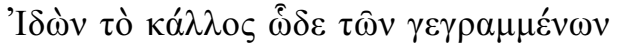

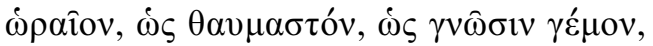

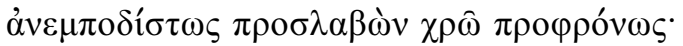

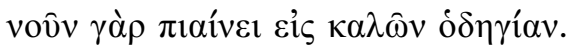

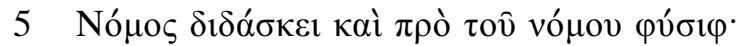

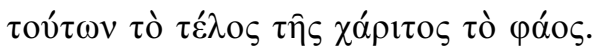

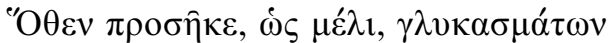

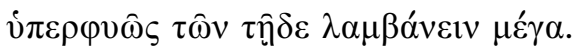

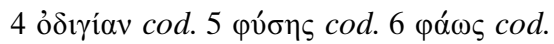

See the beauty of these writings

- how lovely and wonderful, how full of knowledge it is and take it unhindered, use it readily, for it enriches the mind on the way to virtue.

The law gives instructions and so does nature before the law; of these the light of grace is the completion. So it befits to take abundantly, as from honey, from the sweetness contained here.

This epigram (more specifically seven of its verses) can be found at the beginning of various manuscripts containing John Georgides' Gnomologium (s.

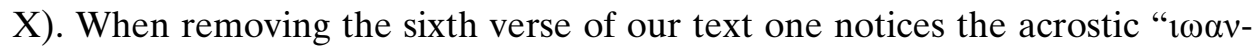
vov", which of course could refer to Georgides. Thanks to Paolo Odorico, however, we know that the poem was originally written by another John, the author of the so-called Florilegium Marcianum, an anthology probably dating from the first half of the ninth century. ${ }^{23} \mathrm{He}$ wrote it as "una nota di lettura"24 on the Catena in Proverbia Salomonis ${ }^{25}$ (preceding the Florilegium in the Codex Marcianus). Georgides, basing his own work on the Florilegium, took over this epigram which was written a century earlier.

Our scribe most probably copied the epigram from one of the tenth- or eleventh-century manuscripts of Georgides' Gnomologium: ${ }^{26}$ they have the

23 Georgides poem has been edited in P. Odorico, Il prato e l'ape: il sapere sentenzioso del

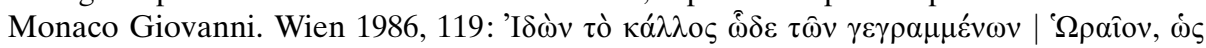

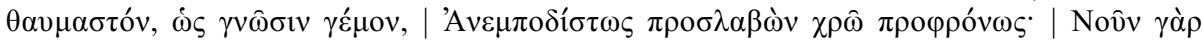

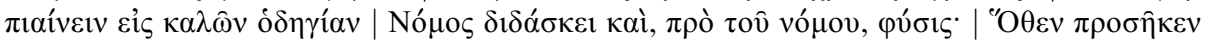

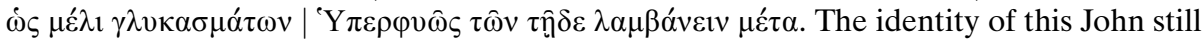
remains obscure, cf. OdoRICO, 17-25. The title of the Florilegium Marcianum is coined by Odorico. It refers to the sole surviving manuscript, the Codex Marcianus Graecus 23.

24 Odorico (cf. note 23) 18.

25 Cf. M. Richard, Le commentaire du codex Marcianus Gr. 23 sur Prov. XXX, 15-33, in M. Richard, Opera Minora. Leuven 1976, III, No 84: 357-370.

26 Odorico (cf. note 23) 61-62 enumerates the following manuscripts: Paris. Suppl. Gr. 1246 (s. X ex.), Paris. Gr. 1166 (s. X ex.), and Laur. Plut. VII. 15 (s. XI med.). 
same deviations from the "original" in the Florilegium Marcianum: $\alpha v \varepsilon \mu \pi \mathrm{o}-$

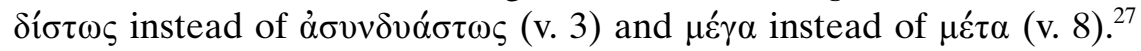

It is clear that the addition of the sixth verse was done by our scribe: besides cutting through the acrostic, it contains the only visible prosodic errors of the poem (the fourth, eighth and tenth syllable fail to be long). This intervention is exemplary for the attitude of scribes towards these poems: they felt entitled to add or leave out elements, according to the new context of the epigram. Preceding a commentary on the Acts of the Apostles, the inserted verse highlights the Christian message of grace spread by the apostles and superseding the teachings of nature and the law (v. 5), subject of the Old Testament Proverbs to which the original version of the poem was related. This poem is therefore exemplary for the procedure of recycling that is so common in book epigrams.

\section{A series of epigrams for Paul}

Source: Vatic. Gr. 363, ff. 239, 257v, 272v, 284, 289. This manuscript (337 folios) was written on parchment and measures 20 by $16.3 \mathrm{~cm}$. The main text consists of the four Gospels (ff. 5-161v), the Acts of the Apostles (ff. 166-210), the Catholic Letters (ff. 211-231) and Paul's Letters (ff. 240-335). Devreesse dated the manuscript to the eleventh/twelfth century. ${ }^{28}$

\section{No 1 (f. 239)}

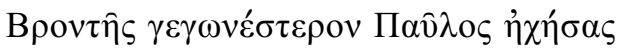

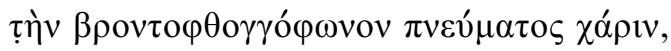

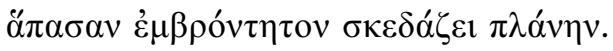

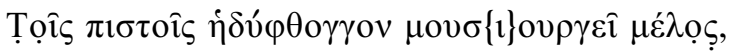

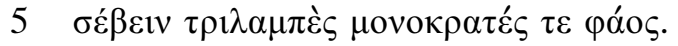

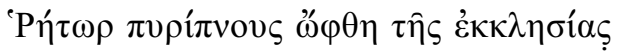

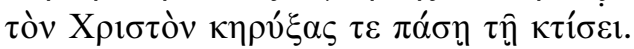

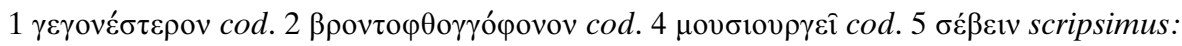

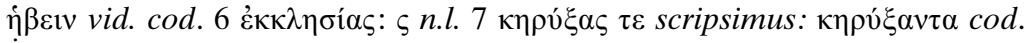

Paul, resounding with the thunder-voiced grace of the Holy Spirit, a sound louder than the thunder,

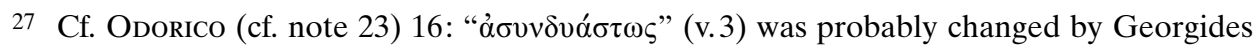

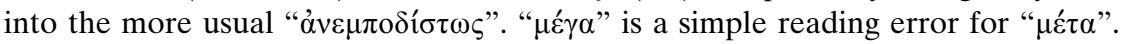

28 R. Devreesse, Codices Vaticani Graeci. Codices 330-603. Città del Vaticano 1937, 50. 
drives away every thunderstruck error.

For the pious he creates a sweet-sounding song,

to worship the light with triple brightness that rules solely.

He showed himself to be a fire-breathing orator of the church, and the proclaimer of Christ for the whole world.

No 2 (f. $257^{v}$ )

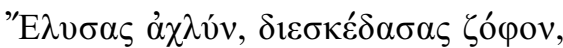

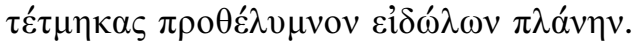

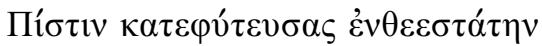

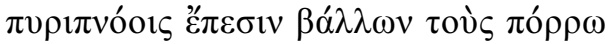

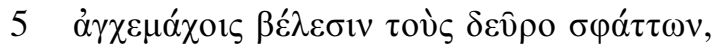

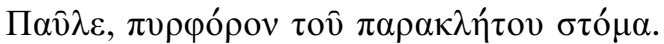

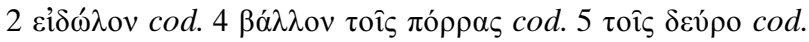

You have dissolved the mist, you have dispersed the darkness, you have rooted out the error of idolatry.

You have planted a faith that is most full of God, pushing forward the people of the future with fire-breathing words, and slaughtering those of the past with hand-to-hand weapons, Paul, fire-bearing mouth of the Holy Spirit.

No 3 (f. $272^{v}$ )

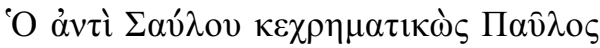

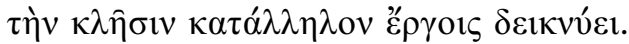

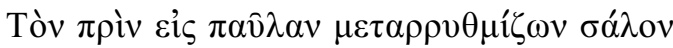

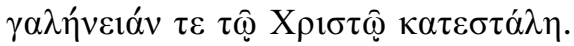

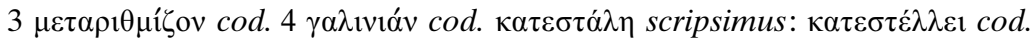

He who has taken the name "Paulus" instead of "Saulus" shows by his works that his name is appropriate. By changing his former tossing into rest and stillness, he has found serenity in Christ. 
No 4 (f. 284)

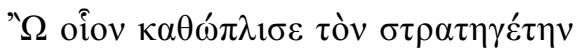

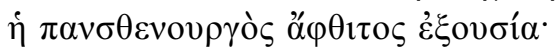

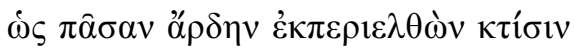

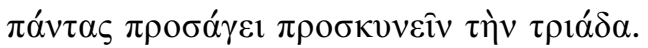

$1 \kappa \alpha \theta \dot{\pi} \lambda \eta \sigma \varepsilon \operatorname{cod}$.

How greatly did the all-powerful everlasting force arm the leader since after having traversed the whole world he prompts all to honour the trinity.

No 5 (f. 289)

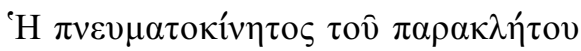

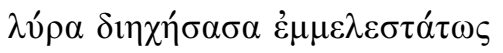

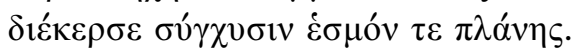

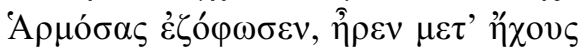

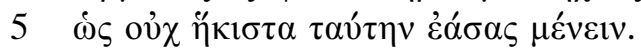

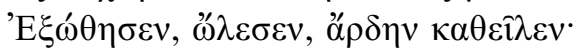

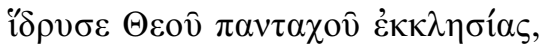

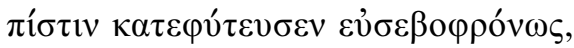

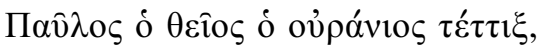

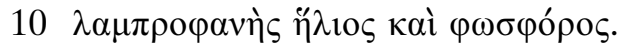

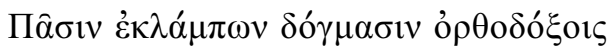

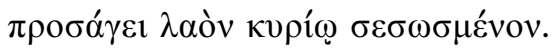

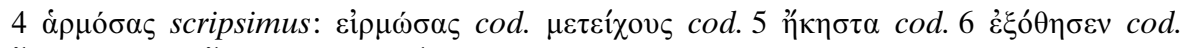

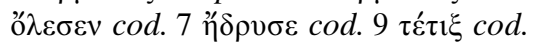

The lyre of the Paraclete, inspired by the Holy Spirit, resounding very harmoniously, cut into pieces the disorder and swarm of digression. Being in tune, he threw it into darkness, he made an end to it with his sound, so that not in the least he has allowed the error to stay.

He drove it out, destroyed it, utterly demolished it. Everywhere he built churches for God, planted faith with a pious mind, Paul, the divine and heavenly cicada, 
the brilliant and light-bringing sun.

Shining with all orthodox doctrines,

he leads the people he has saved towards the Lord.

In the Vaticanus Graecus 363 these five epigrams precede Paul's letters. Most likely they were all written by a single poet, since they share a remarkable number of characteristics regarding content, use of language and metrical features.

All epigrams concentrate on Paul, emphasising his spiritual value for mankind. He is described as the man who repels error. In this context the verbs that are used to mention his deeds are very warlike: $\sigma \kappa \varepsilon \delta \alpha \dot{\zeta} \varepsilon 1$ (poem 1), ${ }^{\prime} \lambda v \sigma \alpha \varsigma$,

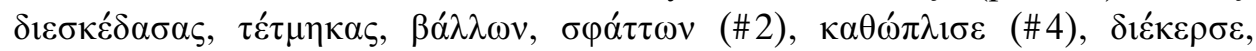

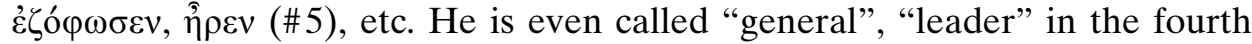

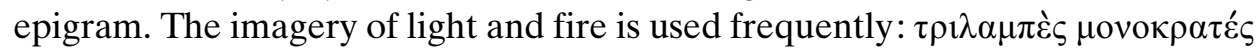

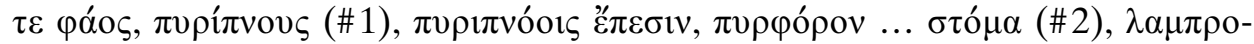

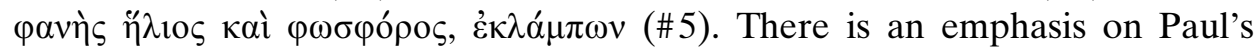

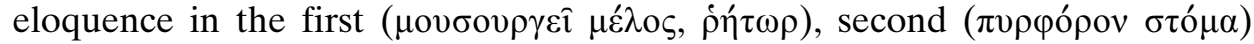
and fifth $(\lambda \hat{v} \rho \alpha, \tau \varepsilon \dot{\tau} \tau 1 \xi)$ epigram. The "musical" imagery to refer to Paul's eloquence reminds of the many laudatory epigrams on David, such as " $\mathrm{H}$

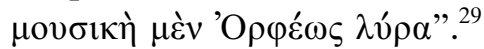

The language of the poems is throughout quite conventional, with a few notable exceptions. The form $\gamma \varepsilon \gamma \omega v \varepsilon \dot{\sigma} \tau \varepsilon \rho \circ v$ (poem 1, v. 1), if correct, is an unattested alternative for $\gamma \varepsilon \gamma \omega v o ́ \tau \varepsilon \rho o v$, coined by analogy. The hapax $\beta \rho \circ v-$

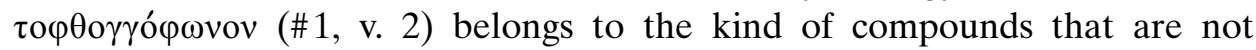
uncommon in Byzantine poetry. All verses typically have twelve syllables, easily recognisable verse pauses and a paroxytonic accent at the end, but the author does not take into account any prosodic rules. Note also that the half

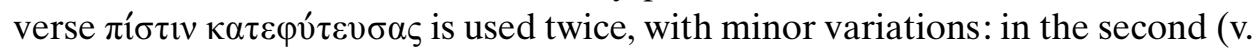
3) and fifth (v. 8) epigram.

These constatations demonstrate that this series of epigrams for Paul is a coherent unity, conceived by one and the same author. It is highly unlikely that the scribe of the Vaticanus Graecus 363 was this author. Not only did he make a considerable number of orthographical and grammatical mistakes, at times he failed fully to understand the text. In the epigram on folio $257 \mathrm{v}$, for example, a later hand has made a sign indicating that in the fifth verse one should not

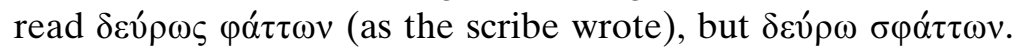

Other obvious failures to understand the text correctly lead to some problematic passages, where the original text can only be reconstructed hypothetically. In poem 3, v. 4, for instance, the manuscript has the non-existing

29 Vatic. Gr. 342, ff. 281v-282. Edited by J.B. Pitra, Analecta sacra spicilegio Solesmensi parata. Parisiis 1884, II 441. 
form $\kappa \alpha \tau \varepsilon \sigma \tau \varepsilon \dot{\lambda} \lambda \lambda \varepsilon 1$. An active present form $\kappa \alpha \tau \alpha \sigma \tau \varepsilon \dot{\lambda} \lambda \lambda \varepsilon 1$ - at first sight the most

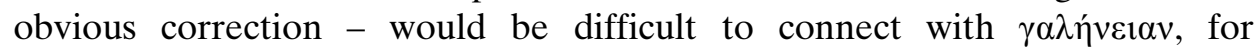
grammatical reasons (the particle $\tau \varepsilon$ would be superfluous), and semantic reasons (the verb $\kappa \alpha \tau \alpha \sigma \tau \dot{\varepsilon} \lambda \lambda \varepsilon \varepsilon$ can mean 'bring to rest' when used with an object with negative value, which is obviously not the case here). We suspect $\kappa \alpha \tau \varepsilon \sigma \tau \alpha \dot{\lambda} \lambda \eta$ to have been the original form. In the passive voice, the verb can mean 'come to a rest', as it does for instance in John Chrysostom's Exp. in Ps. 55.356. Our reading and interpretation of poem 5, v. 4, is even more hesitant: the proposed reconstruction, with forms of $\dot{\alpha} \rho \mu$ ó $\zeta \omega$ (intransitive, 'be in tune') and $\tau$ ò $\eta$ ' $\chi 0 \varsigma$ (a rare neuter), continues the metaphor of Paul as a lyre (see v. 2). Yet, we do not exclude the possibility that the manuscript reading

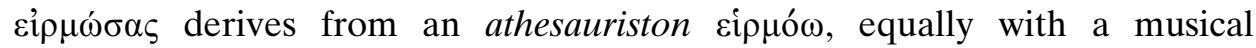
meaning.

It seems, then, that we are dealing here with an earlier collection of epigrams in honour of Paul, lost to us in its original form. Our scribe had recourse to this collection in an attempt to adorn the text of Paul's letters, as a poetic accompaniment and afterthought to a prose text, in the same way that epigrams adorn iconographical representations of religious subjects.

\begin{abstract}
The article offers an edition, translation and commentary of eight so-called book epigrams. They all stem from eleventh-century manuscripts containing the New Testament or commentaries on it, more specifically the Paris. Coisl. 199, the Vindobon. Theol. Gr. 302, the Paris. Coisl. 26, and the Vatic. Gr. 363. While most of them are unedited, the second one is a conflation of known epigrams, and the third an unknown version of a previously edited epigram.

Although book epigrams are frequently encountered in Byzantine manuscripts, the genre has not received much attention. In the track of the recently increasing interest in manuscripts as cultural artifacts in their own right, our commentary focuses on the relationship between epigram and manuscript, and the process of copying. It also discusses textual problems, structure, content, function, vocabulary, and metrical features of the poems.

The analysis is enriched by parallels from other, mostly contemporary, book epigrams, which were collected during an ongoing database project at Ghent University. The comparison shows, among other things, that the material belonging to this genre is 'recyclable': it is constantly re-used, sometimes with slight but meaningful modifications.
\end{abstract}

